\title{
EVALUATING THE RESISTANCE TO THE PLUM POX VIRUS OF SOME APRICOT TREE CULTIVARS AND HYBRIDS IN SOUTH-EASTERN ROMANIA
}

\author{
Marioara Trandafirescu*, Liana Melania Dumitru*, and Iulian Trandafirescu** \\ * Research Station for Fruit Growing Constanta, Pepinierei Str. 1, 907300 Valu lui Traian, ROMANIA; \\ mtrandafirescu@yahoo.com \\ ** Ovidius University of Constanta, Aleea Universitatii, 1, Constanta, ROMANIA
}

Communicated by Edite Kaufmane

\begin{abstract}
In Europe, the Plum pox virus causes one of the most serious diseases of stone fruit-growing species (plum, apricot, peach, nectarine, almond and cherry) in all countries where cultivated. Romania is one of the countries in which this virus has been present for several years and where the contamination level is very high. The disease causes considerable damage, as the infected trees have few fruit, which are small, deformed, lacking in flavour, with a low content of sugar and which can neither be consumed nor used in production. In areas where the Plum pox virus is present, the cultivation of highly resistant (tolerant) genotypes is the only possibility to alleviate this problem. The purpose of the research performed in this paper was to identify varieties that are tolerant to the virus and to monitor the manner in which the resistance is transmitted to hybrid descendants. The material employed consisted of apricot tree varieties from the national collection of the Research Station for Fruit-Growing Constanža. The presence of the Plum pox virus was determined by biological method using a GF305 wooden indicator and the serological method through the ELISA test. The varieties identified as having higher resistance to the attack of the Plum pox virus ('Stark Early Orange', 'NJA 17', and 'Sulmona') were used in intraspecific hybridisations for the selection of hybrids to which this characteristic was transmitted. These included: the selections 'VT 48/45', 'VT 51/45', 'VT 47/112' and ' $H$ 9/5'.
\end{abstract}

Key words: apricot, sharka, biological method, serological method.

The Plum pox virus (PPV) causes one of the most damaging diseases of stone fruit species, such as plum, apricot and peach. Almond and cherry trees may become infected with this virus without obvious symptoms (Festic, 1978; Kalashyan et al., 1994). The virus was artificially transmitted to cherry tree and sour cherry tree, but the infection remained local without evidence that it might spread (Dosba et al., 1987).

The first symptoms of Plum pox virus infection were observed in Bulgaria between 1915 and 1918. Nowadays, the virus is present in most European countries and in Egypt, Syria, Turkey, India, China, Argentina, Chile, USA and Canada.

In Romania, the disease was recorded for the first time in 1922 by Tr. Savulescu and presently, the virus has spread to all the areas where fruit-growing species that have a core are being cultivated, creating massive production losses (Minoiu, 1997; Zagrai et al., 2006).

Because of the severity of this disease, within the European Plant Protection Organisation (OEPP) beginning with 1975, the Plum pox virus has been considered to be a phytosanitary quarantine pathogen, given the fact that it represents a serious threat even in the regions where it has not fully spread yet.

The disease is manifested on leaves, flowers, fruit, the stone and sometimes on the trunk and the skeleton branches (Minoiu, 1997). The intensity of the symptoms vary according to Prunus species cultivar, PPV strain, season, location, tree age and environmental conditions (Levy et al., 2000).

The symptoms are visible during the periods May-June and September-October. During warm summer months, the symptoms are latent and can be observed only on the shady side of trees. Diseased leaves display circular or linear chlorotic spots or light greenish concentric circles and deformations. In general, diseased leaves have the same dimensions as healthy ones.

When fruits are affected, they display circular or elongated spots that are yellow-greenish and with a watery aspect. The diseased fruit are smaller, deformed, with non-uniform colours, less sugar content and a bland taste (Llacer and Cam- 
bra, 1986). In addition, they fall from the tree prematurely. Circular spots can be observed on the stone as well, which are yellow at first and become brown as the core becomes dry (Labonne and Dallot, 2006).

There is no available chemical or biological treatment against this virus. The current solution is to eradicate infected trees and to plant material that is free of the virus. The purpose of the study was to identify genitors resistant to the virus and which are capable of transmitting this characteristic to their hybrid descendants, in view of creating new cultivars resistant to Plum pox virus.

The research carried out within this study was divided into two distinct stages. During the first stage, the aim was to identify cultivars resistant to PPV, with the purpose of using them as genitors within the programme for improvement of the apricot tree.

The material included 635 apricot tree cultivars originating from various ecogeographical areas, which form together the national collection of the Fruit-Growing Research and Development Station Constanža. Each cultivar was represented by five trees, planted at a distance of $4.5 \times 4.0 \mathrm{~m}$.

The choice of cultivars resistant to PPV was carried out by survey of natural infections in the field. In order to highlight viral infections, visual observations of vegetative organs of the trees (leaves, fruits and stones) were performed. The following scale was used to evaluate the intensity of the symptoms of the PPV: $0=$ no symptoms; + = reduced symptoms; $+=$ moderate symptoms; $++=$ strong symptoms; $+++=$ very strong symptoms.

Also, another method was used - indexation based on wooden indicators (GF305). This method consists in passing the virus from an infected individual (the cultivar that is to be tested) to a healthy individual (the indicator) and monitoring the occurrence of specific PPV symptoms.

Subsequent to these tests, the cultivars resistant to PPV were identified and used as genitors for intraspecific hybridisations, which resulted in different hybrid combinations. Then, repeated selections were performed in the hybrid fields F1 and F2, and the hybrids which did not have visual symptoms of PPV were identified. In order to confirm the inheritance of resistance to PPV from their genitors, the hybrids were serologically tested by means of the ELISA test (Clark and Adams, 1977). The advantage of the test is high accuracy for detecting very small quantities of virus (an antigen concentration of $1-10 \mathrm{mg} / \mathrm{ml}$ ) and a rapid reaction speed (results in 6-24 h).

Summary of the data (Table 1) showed that among the 40 apricot tree cultivars, 15 were free of PPV, shown both by visual observation of vegetative organs (leaves, fruits and stones) and by the wooden biological indicator GF305.

These cultivars were used as genitors resistant to Plum pox virus. In order to obtain hybrid descendants in which the selection of resistance to PPV was effective, the choice of the
Table 1

BEHAVIOUR OF SOME APRICOT CULTIVARS TO INFECTION WITH PPV

\begin{tabular}{|c|c|c|c|c|c|}
\hline \multirow[t]{2}{*}{ Tested cultivar } & \multicolumn{3}{|c|}{ Symptoms on: } & \multicolumn{2}{|c|}{$\begin{array}{c}\text { Test on the } \\
\text { indicator GF305 }\end{array}$} \\
\hline & leaves & fruits & stones & reaction & $\begin{array}{c}\text { semnifi- } \\
\text { cation }\end{array}$ \\
\hline Vivagold & 0 & 0 & 0 & - & virus free \\
\hline Sulmona & 0 & 0 & 0 & 0 & virus free \\
\hline $\mathrm{H} 9 / 5$ & 0 & 0 & 0 & - & virus free \\
\hline Mamaia & $(+)$ & 0 & 0 & + & infected \\
\hline Sirena & 0 & 0 & 0 & 0 & virus free \\
\hline Pike & $(+)$ & $(+)$ & ++ & + & infected \\
\hline Umberto & ++ & ++ & +++ & + & infected \\
\hline NJA 14 & ++ & ++ & +++ & + & infected \\
\hline Litoral & + & ++ & $(+)$ & + & infected \\
\hline Sam no 1 & 0 & 0 & 0 & - & virus free \\
\hline Precoce de Colomer & $(+)$ & $(+)$ & 0 & + & infected \\
\hline Earliril & + & ++ & + & + & infected \\
\hline Joubert Foulon & $(+)$ & + & + & + & infected \\
\hline Mari de Cenad & 0 & 0 & 0 & - & virus free \\
\hline Neptun & 0 & 0 & 0 & - & virus free \\
\hline C.R. 2-63 & + & ++ & $(+)$ & + & infected \\
\hline Patriarca Temprano & +++ & +++ & ++ & + & infected \\
\hline NJA 17 & 0 & 0 & 0 & - & virus free \\
\hline R30 P162 & 0 & 0 & 0 & - & virus free \\
\hline R41 P162 & 0 & 0 & 0 & - & virus free \\
\hline Mandula caiszi & +++ & +++ & ++ & + & infected \\
\hline Warley's peach & 0 & 0 & 0 & - & virus free \\
\hline Rouge de Rousillon & ++ & +++ & + & ++ & infected \\
\hline Băneasa 32/29 & +++ & +++ & ++ & ++ & infected \\
\hline CR 24-12 & 0 & 0 & 0 & - & virus free \\
\hline Stark Early Orange & 0 & 0 & 0 & - & virus free \\
\hline Mărculști 72 & ++ & +++ & ++ & ++ & infected \\
\hline Moongold & +++ & +++ & +++ & +++ & infected \\
\hline R9 P53 & 0 & 0 & 0 & - & virus free \\
\hline Farmingdale & ++ & $(+)$ & $(+)$ & + & infected \\
\hline Viceroy & 0 & 0 & 0 & - & virus free \\
\hline NJA 42 & 0 & 0 & 0 & - & virus free \\
\hline Băneasa 3/15 & +++ & +++ & ++ & + & infected \\
\hline RR 15-20 & +++ & +++ & ++ & + & infected \\
\hline Roșii timpurii & + & +++ & +++ & + & infected \\
\hline Băneasa 33/11 & $(+)$ & ++ & $(+)$ & + & infected \\
\hline Sulina & 0 & 0 & 0 & - & virus free \\
\hline Baracca & $(+)$ & ++ & $(+)$ & + & infected \\
\hline Mărculești & +++ & +++ & $(+)$ & + & infected \\
\hline Canino & +++ & +++ & +++ & +++ & infected \\
\hline
\end{tabular}

genitors and correct hybrid combinations are of utter importance. For apricot, the hybridisation formulae must be chosen carefully, especially since some cultivars may manifest a certain level of intersterility, due to which the ability to obtain a $F_{1}$ population of adequate dimensions in which there is a genuine chance of identifying elite plants is extremely limited. The 15 cultivars resistant to PPV ('Viceroy', 'NJA 42', 'Mari de Cenad', 'Neptun', 'Stark Early Orange', 'Sam no.1', 'CR 24-12', 'H 9/5', 'Sirena', 
HYBRID COMBINATIONS OF APRICOT TREE USING GENITORS RESISTANT TO PPV

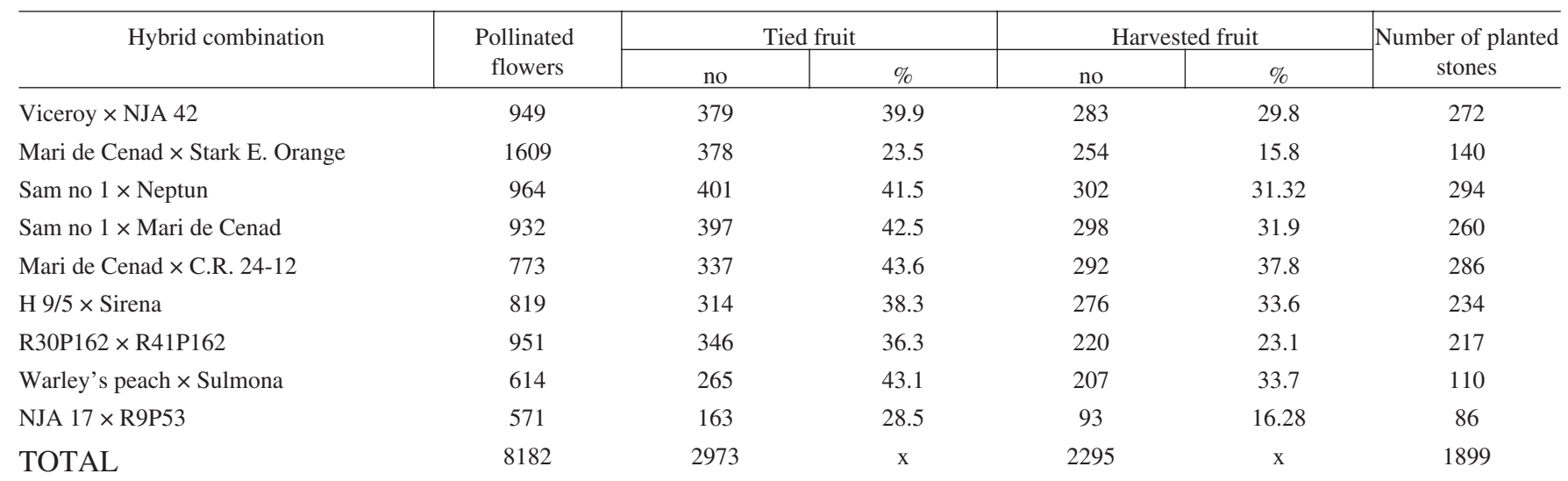

'R30P162', 'R41P162', 'Warley’s peach', 'Sulmona', 'NJA 17 ' and 'R9P53'), were used to create nine hybrid combinations, presented in Table 2, with a total of 8182 pollinated flowers.

The pollinated flowers resulted in 2973 hybrid fruit, from which we obtained 1899 good stones that were planted in the field. The 15 apricot tree genotypes used in hybridisations included other important features, apart from resistance to PPV, such as: medium and low vigour; large, high quality fruit; good productivity; resistance to extreme cold, drought and pathogen agents and others.

The apricot tree hybrid descendents were serologically tested by means of the immunoenzymatic ELISA test, which measures the infection with PPV, and were categorised into three groups: sensitive, partially resistant and resistant.

From the group of resistant hybrids (Table 3), we would like to note the following selections: 'R8P71-73.10.74', 'R8P79-73.10.74', 'VT 47/112', 'VT 48/53', 'VT 51/45', 'VT 48/45', 'VT 4/73', 'VT 30/103', 'VT 34/72', '91.07.91', '91.35.59' and '92.02.54'. Some of these selections were registered ('Tudor', 'Traian', 'Auras', 'Danubiu', 'Cristal', 'Fortuna', 'Amiral', 'Orizont' and 'Augustin') in the period between 2003 and 2004, while others ('Euxin', 'Histria' and 'Ceres') were approved in 2010.

Subsequent to this research, it is recommended that improvement programmes use genitors that are resistant or tolerant to PPV, in order to obtain new apricot tree cultivars resistant to the infection with this virus. It is also recommended that all testing techniques be used, including molecular methods, in order to highlight with certainty the presence of the virus within certain genotypes, since this is the only way in which we can be absolutely sure that the spreading of the damaging virus is held effectively under control.

\section{ACKNOWLEDGEMENTS}

This work was financed by UMPP - ASAS Bucuresti, Sectorial Plan ADER 2020, Project ADER 2.2.7., Contract $227 / 2011$.

PPV DETECTION ON CERTAIN APRICOT TREE SELECTIONS BY MEANS OF THE ELISA TEST

\begin{tabular}{|c|c|c|c|c|}
\hline \multirow[b]{2}{*}{$\begin{array}{c}\text { Hybrid } \\
\text { combination }\end{array}$} & \multirow[b]{2}{*}{ Selection } & \multirow{2}{*}{$\begin{array}{c}\text { Name of the } \\
\text { registrated } \\
\text { variety }\end{array}$} & \multicolumn{2}{|c|}{ ELISA test } \\
\hline & & & $\begin{array}{l}\text { semnifi- } \\
\text { cation }\end{array}$ & value \\
\hline Viceroy $\times$ NJA 42 & $\begin{array}{l}\text { R8 P71 } \\
73.10 .74\end{array}$ & Tudor & negative & 0.421 \\
\hline Viceroy $\times$ NJA 42 & $\begin{array}{l}\text { R8 P79 } \\
73.10 .74\end{array}$ & Traian & negative & 0.446 \\
\hline $\begin{array}{l}\text { Mari de Cenad } \times \text { S.E. } \\
\text { Orange }\end{array}$ & VT $47 / 112$ & Aura & negative & 0.402 \\
\hline Sam no $1 \times$ Neptun & VT $48 / 53$ & Danubiu & negative & 0.452 \\
\hline $\begin{array}{l}\text { Sam no } 1 \times \text { Mari de } \\
\text { Cenad }\end{array}$ & VT $51 / 45$ & Cristal & negative & 0.456 \\
\hline $\begin{array}{l}\text { Sam no } 1 \times \text { Mari de } \\
\text { Cenad }\end{array}$ & VT $48 / 45$ & Fortuna & negative & 0.459 \\
\hline $\begin{array}{l}\text { Mari de Cenad } \times \text { CR } \\
24-12\end{array}$ & VT $4 / 73$ & Amiral & negative & 0.465 \\
\hline $\begin{array}{l}\text { Mari de Cenad } \times \text { CR } \\
24-12\end{array}$ & VT $30 / 103$ & Orizont & negative & 0.473 \\
\hline H $9 / 5 \times$ Sirena & VT $34 / 72$ & Augustin & negative & 0.474 \\
\hline $\mathrm{R} 30 \mathrm{P} 162 \times \mathrm{R} 41 \mathrm{P} 162$ & 91.07 .91 & Euxin & negative & 0.474 \\
\hline $\begin{array}{l}\text { Warleys peach } \times \\
\text { Sulmona }\end{array}$ & 91.35 .59 & Histria & negative & 0.483 \\
\hline NJA $17 \times$ R9P53 & 92.02 .54 & Ceres & negative & 0.537 \\
\hline Positive control & - & - & - & 2.254 \\
\hline Negative control & - & - & - & 0.579 \\
\hline
\end{tabular}

\section{REFERENCES}

Clark, M. F., Adams, A. N. (1977). Characteristic of the microplate method of enzyme linked inunosorbent assay for the detection of plant viruses. J. Gen. Virol., 34, 475-483.

Dosba, F., Maison P., Lansac, M., Massone, G. (1987). Experimental transsmision of Plum pox virus (PPV) to Prunus mahaleb and Prunus avium. J. Phytopathol., 120, 199-204.

Festie, H. (1978). Investigation of new sharka virus hosts. Acta Hort., No. 74, 233-240. 
Kalashjan, Ju. A., Bilkey, N. D., Verderevskaya, T. D., Rubina, E. V. (1994). Plum pox poty virus on sour cherry in Moldova. EPPO Bull. (European and Mediterranean Plant Protection Organization), 24, 645-649.

Labonne, G., Dallot, S. (2006). Epidemiology of sharka disease in France. EPPO Bull., 36, 267-270.

Levy, L., Demsteegt, V., Scorza, R., Kolber, M., (2000). Plum pox potyvirus disease of stone fruits. APSnet Features. DOI: 10.1094/APSnetFeature-2000-0300

Llacer, G., Cambra, M. (1986). Occurence of Plum pox virus in Spain in a new natural host: Prunus salicina Lindl (Japanese plum). Plant Dis., 70,

Received 25 March 2013
Minoiu, N. (1997). Regenerarea prin devirozare a pomilor fructiferi [Regeneration of Fruit-growing Trees by Means of Devirusing]. Bul. Inf. Hort., 13, 9-10 (in Romanian).

Nemeth, M. (1986). Virus, Mycoplasma and Rickettsie Diseases of Fruit Trees. Budapest: Akad. Kiada. 750 pp.

Smith, I. E., Condresse, T., Dosba, F. (1994). La Sharka, ou en est-on en Europe et ailleurs? Arboricult. Fruit., 41 (471) 29-52.

Zagrai, I., Gaboreanu, I., Ferencz, B., Zagrai, L., Pamfil D., Popescu O., Rovelonandro M., Capote N., Kovacs, K. (2006). First detection and molecular characterization of Plum Pox Virus recombinant strain in Romania. Buletin USAMV-CN, 62, 291-298.

\section{APRIKOŽU ŠKIRNU UN HIBRĪDU REZISTENCES PRET PLŪMJU BAKU VĪRUSU VĒRTĒJUMS RUMĀNIJAS DIENVID- AUSTRUMU DAL $\bar{A}$}

Šobrīd Eiropā plūmju baku vīruss izraisa vienu no vissmagākajām slimībām, kas skar kaulen̨koku sugas (plūmes, aprikozes, persikus, nektarīnus, mandeles un k̦iršus) visās to audzēšanas valstīs. Rumānija ir viena no valstīm, kurā šis vīruss ir sastopams jau vairākus gadus un kurā ir l̦oti augsts inficēšanās līmenis. Slimība izraisa ievērojamu kaitējumu, jo inficētajiem kokiem ir maz augḷu, tie ir mazi un deformēti, bezgaršīgi, ar zemu cukura saturu, nav izmantojami ne svaigā veidā, ne pārstrādei. Tāpēc reǵionos, kur plūmju baku vīruss ir izplatīts, vienīgā pieejamā iespēja vīrusa izraisīto bojājumu samazināšanai ir audzēt augsti izturīgus (tolerantus) genotipus. Šì pētījuma mērkis bija noteikt šķirnes, kas ir izturīgas pret vīrusa infekciju, kā arī novērtēt veidu, kādā izturība tiek pārmantota hibrīdajos pēcnācējos. Pētījumā izmantots aprikožu škirnes no auglkopības pētījumu stacijas Constanža nacionālās kolekcijas. Plūmju baku vīrusa noteikšana veikta, izmantojot bioloğisko metodi, kas ietver testus uz GF305 indikatorauga, un seroloğisko metodi ar ELISA testu. Augstākā izturība pret plūmju baku vīrusa infekciju tika konstatēta šķirnēm 'Stark Early Orange', 'NJA 17', 'Sulmona', kuras tika izmantotas kā vecākaugi iekšsugas krustojumos, lai atlasītu hibrīdus, kas mantojuši izturību. No iegūtajiem hibrīdiem kā izturīgi minami 'VT 48/45', 'VT 51/45', 'VT 47/112', 'H 9/5'. 